Article

\title{
Glass Forming Ability and Corrosion Resistance of Zr-Cu-Ni-Al-Ag Bulk Metallic Glass
}

\author{
Wei Zhou *, Caiwei Zhang, Minqi Sheng and Jixin Hou * \\ Shagang School of Iron and Steel, Soochow University, Suzhou 215021, China; \\ qibao950902@163.com (C.Z.); shengminqi@suda.edu.cn (M.S.) \\ * Correspondence: wzhou@suda.edu.cn (W.Z.); houjixin@suda.edu.cn (J.H.); Tel.: +86-521-6716-4815 (J.H.) \\ Academic Editor: K.C. Chan \\ Received: 13 July 2016; Accepted: 20 September 2016; Published: 24 September 2016
}

\begin{abstract}
Zr}_{70-x} \mathrm{Cu}_{12.5} \mathrm{Ni}_{10} \mathrm{Al}_{7.5} \mathrm{Ag}_{x}(x=0-10)$ bulk metallic glasses (BMGs) have been prepared by copper mold casting. The glass-forming ability (GFA) and corrosion behavior of Zr-based BMGs have been investigated. It is found that the GFA of Zr-based BMGs first increases and then decreases with the increase of the $\mathrm{Ag}$ content, and the best glass former is $\mathrm{Zr}_{65} \mathrm{Cu}_{12.5} \mathrm{Ni}_{10} \mathrm{Al}_{7.5} \mathrm{Ag}_{5}$ with the maximum thickness of the glass phase region of $4.3 \mathrm{~mm}$. The corrosion resistance is, however, found to be worsened with the increase of the Ag content. The mechanisms for the enhancement of GFA and the deterioration of corrosion resistance in the alloys are discussed.
\end{abstract}

Keywords: Zr-based bulk metallic glass; glass-forming ability; corrosion behavior

\section{Introduction}

Due to the absence of long-range atomic order, bulk metallic glasses (BMGs) exhibit unique mechanical, physical and chemical properties, and therefore have obtained preliminary applications in fields of sporting goods, precision machinery parts, electronic information, and biomedicine [1-6]. However, as for a number of BMG-forming alloys, small-size BMGs can be fabricated, which restricts their wide application. Two methods can be used to overcome the drawback: enhancing the cooling rate in preparation and adjusting the alloy composition [7,8]. Considering that the equipment requirement is relatively high for the former method, most researchers used the latter one. Minor alloying has been proved to be a simple and effective way to develop large-size BMGs, such as Pd- [9,10], Fe- [11], Co- [12], Ni- [13], Mg- [14], Cu- [15], and Zr-based [16] BMGs. Among them, Zr-based BMGs have attracted increasing attention due to their high glass-forming ability and wide supercooled liquid region. At present, many Zr-based alloy systems have been developed, such as Zr-Cu-Al [17], Zr-Cu-Ti [18], Zr-Cu-Ag-Al [19], Zr-Cu-Ni-Al [20], and Zr-Cu-Ni-Al-Ti [21] BMGs. In this study, based on the $\mathrm{Zr}_{70} \mathrm{Cu}_{12.5} \mathrm{Ni}_{10} \mathrm{Al}_{7.5}$ alloy system, we develop new $\mathrm{Zr}_{70-x} \mathrm{Cu}_{12.5} \mathrm{Ni}_{10} \mathrm{Al}_{7.5} \mathrm{Ag}_{x}$ BMGs with the addition of the element Ag. The glass-forming ability (GFA) and corrosion behavior of Zr-based BMGs have been systematically investigated.

\section{Experiment}

Master alloy ingots with nominal composition of $\mathrm{Zr}_{70-x} \mathrm{Cu}_{12.5} \mathrm{Ni}_{10} \mathrm{Al}_{7.5} \mathrm{Ag}_{x}(x=1-10)$ were prepared by arc melting a mixture of pure $\mathrm{Zr}(99.9 \%), \mathrm{Cu}(99.99 \%), \mathrm{Ni}(99.99 \%), \mathrm{Al}(99.99 \%)$, and Ag (99.99\%) using a WS-4 vacuum non consumable arc furnace (SKY Technology Development Ltd., Shenyang, China) in a purified argon atmosphere. Before melting, the pure metals were cleaned in an ultrasonic cleaning bath. After six times remelting, the BMGs were produced by suction-casting for wedge-shape plates with an inclined angle of $10^{\circ}$ and $60-\mathrm{mm}$-long rectangular plates of thickness and width $1 \mathrm{~mm}$ and $10 \mathrm{~mm}$, respectively. Maximum thickness of fully glass phase in the wedge-shape sample was measured by examining the cross-sectional structure in 
the central region with an optical microscope (OM, OLYMPUS Ltd., Tokyo, Japan). After OM examination, the wedge-shape samples were cut transversely at the maximum thickness of glass phase region. The microstructure of wedge-shape glass samples was investigated by Thermo ARL $\mathrm{X}$-ray diffractometer (XRD, Smart Lab, Tokyo, Japan) with monochromatic $\mathrm{CuK} \alpha$ radiation and JEOL JEM-2100F high-resolution transmission electron microscopy (HRTEM, JEOL Ltd., Akishima, Japan). The TEM foils were prepared by electrochemical twin-jet polishing in a solution of $5 \%$ perchloric acid and $95 \%$ ethanol at $233 \mathrm{~K}$, followed by ion milling with liquid nitrogen cooling. Thermal analyses were carried out on Perkin-Elmer Pyris Diamond differential scanning calorimeter (DSC, Perkin Elmer Ltd., Waltham, MA, USA) at a constant heating rate of $20 \mathrm{~K} / \mathrm{min}$ under a flow of high purity argon. Melting behaviors were studied by a Netzsch 404F3 differential thermal analysis (DTA, NETZSCH Ltd., Selb, Germany) at a heating rate of $20 \mathrm{~K} / \mathrm{min}$. Corrosion behaviors of the plate samples were evaluated by electrochemical polarization measurement, which were conducted in a three-electrode cell, consisting of a test sample, a platinum counter electrode and a standard saturated calomel reference electrode (SCE, CH Instruments Inc., Austin, TX, USA). Before polarization scan, the sample was immersed in the electrolytes of $3.5 \% \mathrm{NaCl}$ solutions for $20 \mathrm{~min}$ so that the open circuit potential became almost steady. The electrochemical polarization measurement was examined at a potential sweep rate of $2 \mathrm{mV} / \mathrm{s}$. At least four electrochemical measurements were conducted for an alloy to obtain reliable results. Surface of the corroded specimens after electrochemical polarization measurement were carefully examined using a SU5000 scanning electron microscope (SEM, HITACHI Ltd., Tokyo, Japan).

\section{Results and Discussion}

The maximum thickness of the glass phase region $\left(t_{c}\right)$ is a simple and intuitive parameter to characterize the GFA of the alloy. A large $t_{\mathrm{c}}$ reflects a high GFA. In this study, $t_{\mathrm{c}}$ was used to evaluate the GFA of the alloy. Figure 1 shows the variation of $t_{c}$ with respect to the Ag content in the wedge-shaped sample for the $\mathrm{Zr}_{70-x} \mathrm{Cu}_{12.5} \mathrm{Ni}_{10} \mathrm{Al}_{7.5} \mathrm{Ag}_{x}$ alloys. As is seen, the value of $t_{\mathrm{c}}$ is $2.5 \mathrm{~mm}$ for the $\mathrm{Zr}_{70} \mathrm{Cu}_{12.5} \mathrm{Ni}_{10} \mathrm{Al}_{7.5}$ alloy. After the addition of $\mathrm{Ag}$, the $t_{\mathrm{c}}$ first increases with the increase of the $\mathrm{Ag}$ content, and reaches its maximum around $4.3 \mathrm{~mm}$, at the composition of $\mathrm{Zr}_{65} \mathrm{Cu}_{12.5} \mathrm{Ni}_{10} \mathrm{Al}_{7.5} \mathrm{Ag}_{5}$. With further increasing the $\mathrm{Ag}$ content, the $t_{\mathrm{c}}$ gradually decreases. When the $\mathrm{Ag}$ content reaches $10 \%$, the $t_{\mathrm{c}}$ decreases up to $2.8 \mathrm{~mm}$. These results suggest that the addition of the appropriate amount of $\mathrm{Ag}$ is beneficial to glass phase formation for the $\mathrm{Zr}_{70-x} \mathrm{Cu}_{12.5} \mathrm{Ni}_{10} \mathrm{Al}_{7.5} \mathrm{Ag}_{x}$ alloys, and the best glass former is the $\mathrm{Zr}_{65} \mathrm{Cu}_{12.5} \mathrm{Ni}_{10} \mathrm{Al}_{7.5} \mathrm{Ag}_{5}$ alloy.

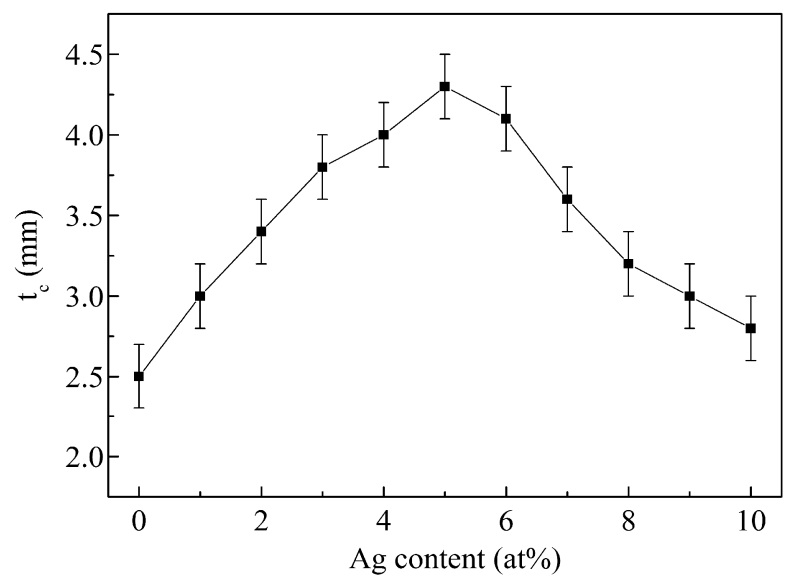

Figure 1. Dependence of maximum thickness of glass phase region $\left(t_{c}\right)$ on the Ag content in the wedge-shaped samples for the $\mathrm{Zr}_{70-x} \mathrm{Cu}_{12.5} \mathrm{Ni}_{10} \mathrm{Al}_{7.5} \mathrm{Ag}_{x}$ alloys.

The XRD patterns of the fully glass phase region for the $\mathrm{Zr}_{70-x} \mathrm{Cu}_{12.5} \mathrm{Ni}_{10} \mathrm{Al}_{7.5} \mathrm{Ag}_{x}$ alloys consist of two broad diffused peaks without any detectable crystalline diffraction peak, as shown in Figure 2. 
HRTEM was used to carefully investigate the microstructure of the alloys. Figure 3 presents the bright field image and selected area electron diffraction (SAED) pattern of the alloys with $x=0$ and $x=5$. The homogeneous contrast without any distinguishable crystallites in the image and a broad halo in the SAED pattern indicate the formation of a single amorphous phase. In addition, a similar structure has been observed in other alloys.

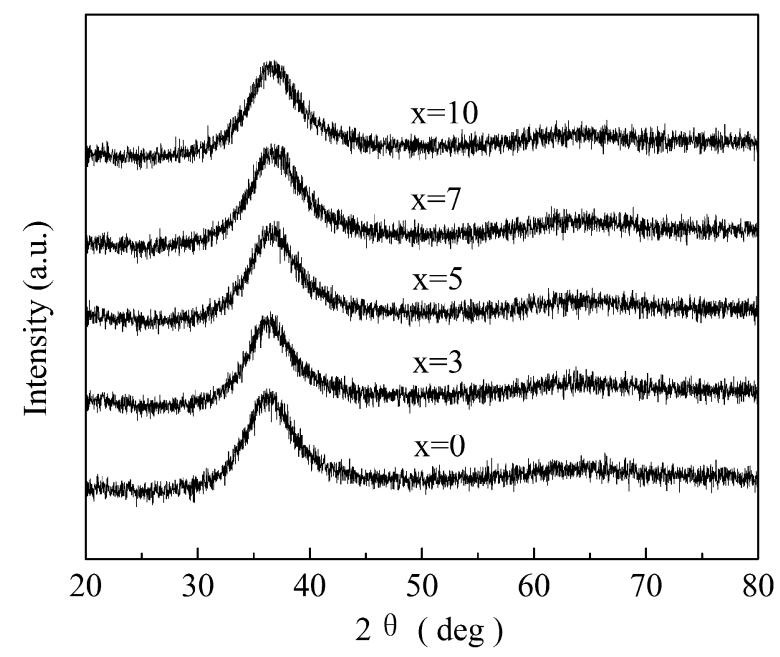

Figure 2. $\mathrm{XRD}$ patterns of the $\mathrm{Zr}_{70-x} \mathrm{Cu}_{12.5} \mathrm{Ni}_{10} \mathrm{Al}_{7.5} \mathrm{Ag}_{x}$ alloys.
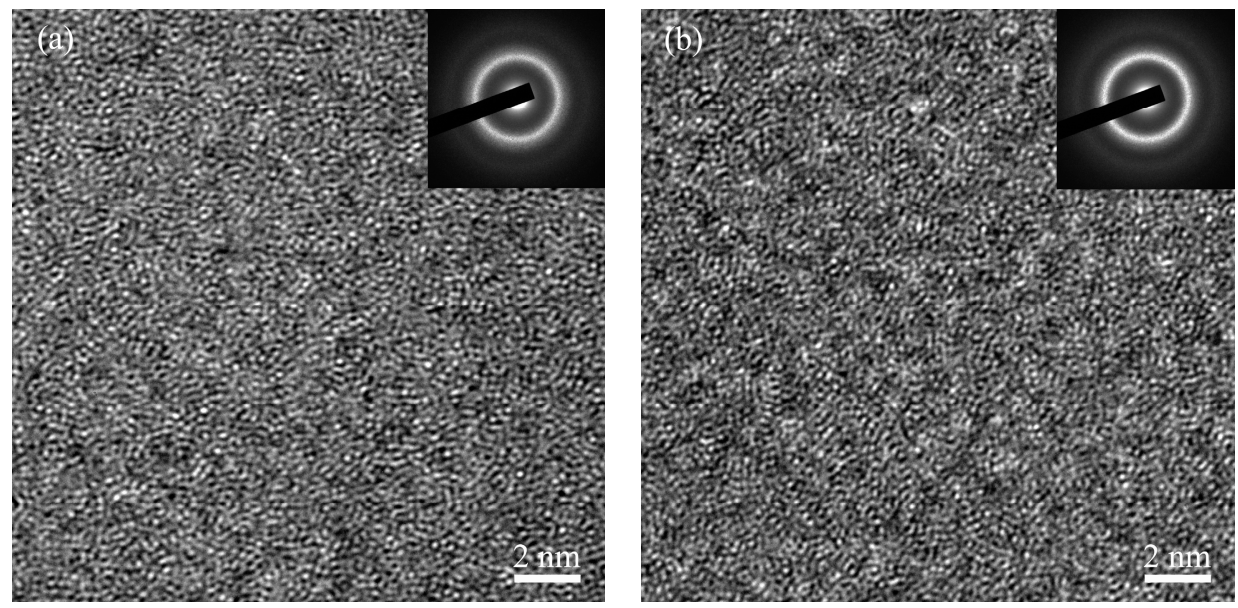

Figure 3. High resolution TEM images and SAED patterns of $\mathrm{Zr}_{70} \mathrm{Cu}_{12.5} \mathrm{Ni}_{10} \mathrm{Al}_{7.5}$ (a); and $\mathrm{Zr}_{65} \mathrm{Cu}_{12.5} \mathrm{Ni}_{10} \mathrm{Al}_{7.5} \mathrm{Ag}_{5}$ (b) alloys.

The formation of the glass phase is determined by two factors: the GFA of the alloy and the preparation condition. In this study, the fabrication process condition is strictly controlled. The preparation condition for each alloy is almost the same. Therefore, the intrinsic property of the alloy is the key factor for glass phase formation. As for the alloy system itself, negative heats of mixing and the large difference in the atomic size among the components are favorable for the formation of the glass phase. In this study, the substitution of $\mathrm{Zr}$ with Ag causes an increase in the number of components $(4 \rightarrow 5)$, and the interactions among the components become more complicated, which is favorable for glass phase formation to a certain extent [22,23]. The heats of mixing among the components and the atomic radius for the $\mathrm{Zr}-\mathrm{Cu}-\mathrm{Ni}-\mathrm{Al}-\mathrm{Ag}$ alloy system are displayed in Table 1 . The addition of element $\mathrm{Ag}$ has positive heats of mixing with $\mathrm{Cu}$ and $\mathrm{Ni}(\mathrm{Ag}-\mathrm{Cu}:+2 \mathrm{~kJ} / \mathrm{mol} ; \mathrm{Ag}-\mathrm{Ni}$ : $+15 \mathrm{~kJ} / \mathrm{mol}$ ) [24] but negative heats of mixing with $\mathrm{Zr}$ and $\mathrm{Al}$, and it especially has a strong attractive interaction with the main constituent element $\mathrm{Zr}(\mathrm{Ag}-\mathrm{Zr}$ : $-20 \mathrm{~kJ} / \mathrm{mol})$ [24]. The former can weaken 
the interaction among components, while the latter can enhance their interactions. According to Miedema's model [25], the chemical mixing enthalpy $\left(\Delta H_{\text {chem }}\right)$ of regular solution in liquid phase for a multi-component alloy can be expressed as:

$$
\Delta H_{\text {chem }}=\sum_{i=1, i \neq j}^{n} \Omega_{i j} c_{i} c_{j}
$$

where $i$ and $j$ refer to the two elements, $c$ is the atomic percentage, $\Omega_{i j}$ is the interaction between the two alloying elements and can be calculated by the mixing enthalpy of the binary alloy in liquid phase: $\Omega_{i j}=4 \Delta H_{\mathrm{AB}}$. Figure 4 displays the relationship between the chemical mixing enthalpy $\left(\Delta H_{\text {chem }}\right)$ and $\mathrm{Ag}$ concentration. The curve of variation of $\Delta H_{\text {chem }}$ with the Ag content represents the tendency of increasing in the beginning and decreasing at last with the increase of the Ag content, which is of a parabolic type. The maximum negative value of $\Delta H_{\text {chem }}$ appears in the alloy with $x=4$, which is basically consistent with the change of $t_{\mathrm{c}}$. Moreover, the atomic radius of components in the $\mathrm{Zr}-\mathrm{Cu}-\mathrm{Ni}-\mathrm{Al}-\mathrm{Ag}$ alloy system decreases sequentially in the order: $\mathrm{Zr}(1.60 \AA), \mathrm{Ag}(1.44 \AA)$, $\mathrm{Al}(1.43 \AA), \mathrm{Cu}(1.28 \AA), \mathrm{Ni}(1.24 \AA)$. Ag is the second-largest atom in the alloy system with a large difference in the atomic size ratios of $\mathrm{Ag}-\mathrm{Zr}(25.0 \%), \mathrm{Ag}-\mathrm{Cu}(12.5 \%)$ and $\mathrm{Ag}-\mathrm{Ni}(16.1 \%)$. The large discrepancy in the atomic size among the constituent elements is beneficial to the formation of a highly dense, random-packed structure in melt, leading to the increase of the liquid/solid interfacial energy and the suppression of the long-range diffusion of atoms. Consequently, the alloy system possesses a higher activation energy so as to easily form the glass phase by suppressing the nucleation of the melt. Therefore, the appropriate amount of Ag can effectively enhance the GFA of the $\mathrm{Zr}_{70-x} \mathrm{Cu}_{12.5} \mathrm{Ni}_{10} \mathrm{Al}_{7.5} \mathrm{Ag}_{x}$ alloys.

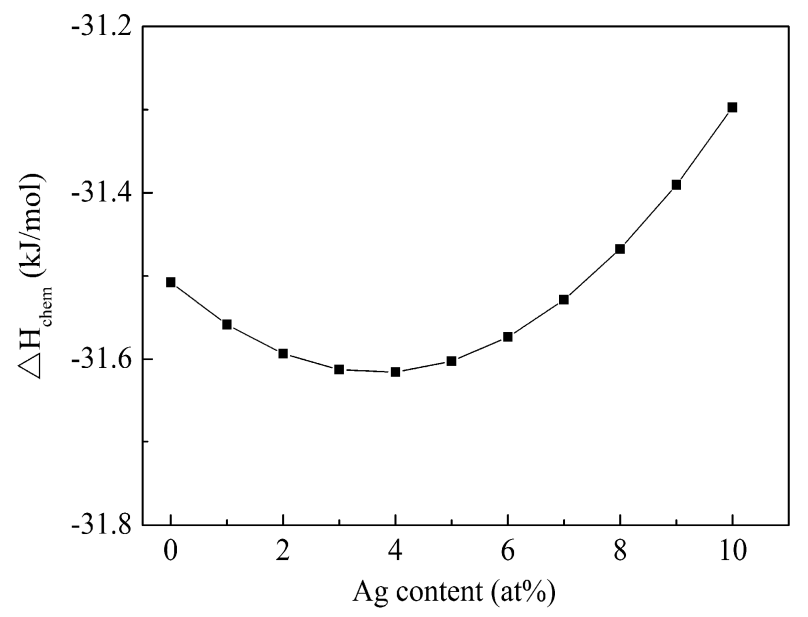

Figure 4. Dependence of chemical mixing enthalpy $\left(\Delta H_{\text {chem }}\right)$ on the Ag content.

Table 1. Heat of mixing and atomic radius for alloying elements.

\begin{tabular}{cccccc}
\hline Element & Zr & $\mathbf{C u}$ & $\mathbf{N i}$ & Al & Ag \\
\hline $\mathrm{Zr}(1.60 \AA)$ & - & -23 & -49 & -44 & -20 \\
$\mathrm{Cu}(1.28 \AA)$ & - & - & +4 & -1 & +2 \\
$\mathrm{Ni}(1.24 \AA)$ & - & - & - & -22 & +15 \\
$\mathrm{Al}(1.43 \AA)$ & - & - & - & - & -4 \\
$\mathrm{Ag}(1.44 \AA)$ & - & - & - & - & - \\
\hline
\end{tabular}

Figure 5 shows DSC and DTA curves obtained from wedge-shaped $\mathrm{Zr}_{70-x} \mathrm{Cu}_{12.5} \mathrm{Ni}_{10} \mathrm{Al}_{7.5} \mathrm{Ag}_{x}$ alloys during continuous heating at $20 \mathrm{~K} / \mathrm{min}$. An obvious endothermic event associated with glass transition and two or three exothermic crystallization peaks were observed in the DSC curves. As seen 
in the DTA curves, the melting temperature $\left(T_{\mathrm{m}}\right)$ and liquidus temperature $\left(T_{1}\right)$ are marked with arrows. The melting temperature range $\left(\Delta T_{\mathrm{m}}=T_{1}-T_{\mathrm{m}}\right)$ initially increases and then almost decreases with the Ag content. A quite wide melting peak for each alloy was observed in the melting process, suggesting that the compositions of $\mathrm{Zr}_{70-x} \mathrm{Cu}_{12.5} \mathrm{Ni}_{10} \mathrm{Al}_{7.5} \mathrm{Ag}_{x}$ alloys are at off-eutectic point.
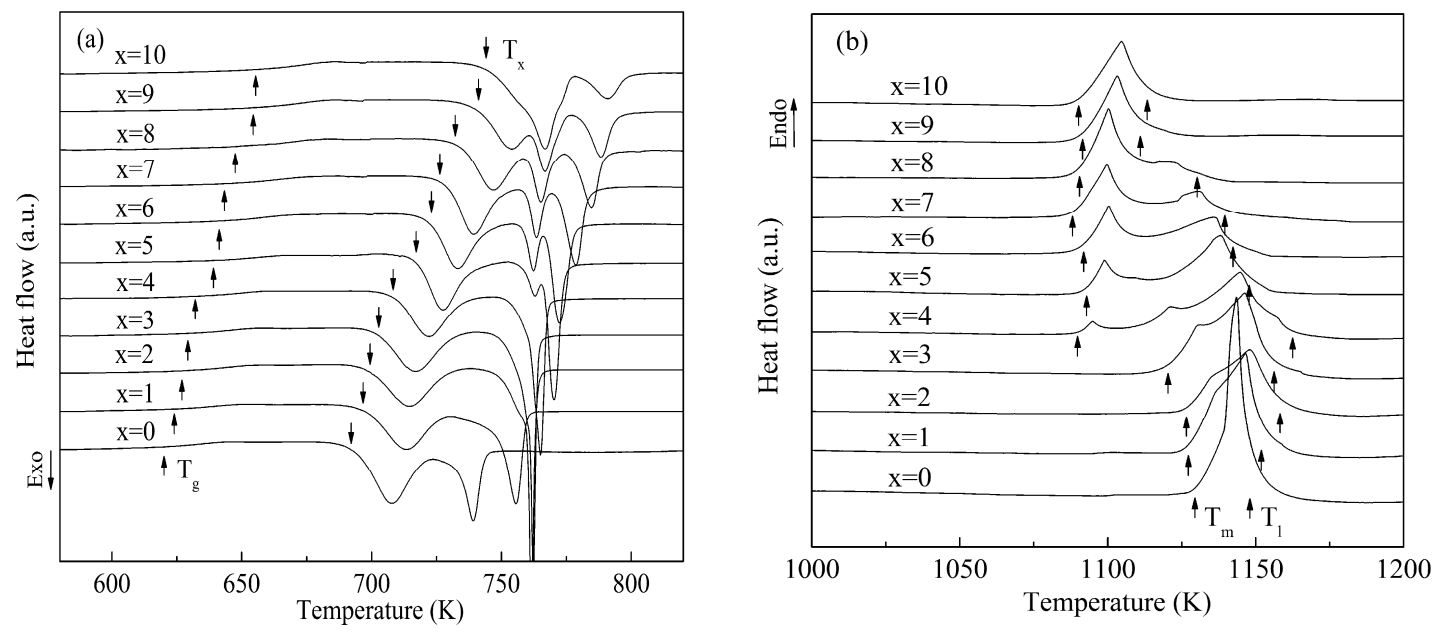

Figure 5. DSC (a); and DTA (b) curves of the $\mathrm{Zr}_{70-x} \mathrm{Cu}_{12.5} \mathrm{Ni}_{10} \mathrm{Al}_{7.5} \mathrm{Ag}_{x}$ alloys.

Based on the DSC and DTA curves, variations of the glass transition temperature $\left(T_{\mathrm{g}}\right)$ and the crystallization onset temperature $\left(T_{x}\right)$, the supercooled liquid region $\left(\Delta T_{x}=T_{x}-T_{\mathrm{g}}\right)$, the reduced glass transition temperature $\left(T_{\mathrm{rg}}=T_{\mathrm{g}} / T_{1}\right)$, and the parameter $\gamma=T_{x} /\left(T_{\mathrm{g}}+T_{1}\right)$ with respect to Ag content are presented in Figure 6. It is seen that $T_{\mathrm{g}}$ and $T_{x}$ monotonously increase from 619 and $692 \mathrm{~K}$ to 654 and $741 \mathrm{~K}$, respectively, with the increasing $\mathrm{Ag}$ content combined with a remarkable increase of the supercooled liquid region $\Delta T_{x}$ from 73 to $87 \mathrm{~K}$. Besides $T_{x}$, the parameters $T_{\operatorname{rg}}$ and $\gamma$ increase with the Ag content, which is inconsistent with $t_{\mathrm{c}}$, suggesting that $\Delta T_{x}, T_{\mathrm{rg}}$ and $\gamma$ are not very sensitive to the GFA for $\mathrm{Zr}_{70-x} \mathrm{Cu}_{12.5} \mathrm{Ni}_{10} \mathrm{Al}_{7.5} \mathrm{Ag}_{x}$ alloys. Such a discrepancy between the GFA and these empirical parameters has also been reported in the $\mathrm{Cu}-\mathrm{Zr}$ [26] and La-Al-Cu-Ni [27] alloy systems with the optimum glass-forming composition located at the off-eutectic point. This phenomenon is related to phase selection during the rapid solidification of the alloys [28]. In addition, the Ag addition can effectively improve the thermal stability. The enhancement of thermal stability for the alloy is due to suppressing the redistribution of components to form the I-phase by partial substitution of $\mathrm{Zr}$ with Ag [29].
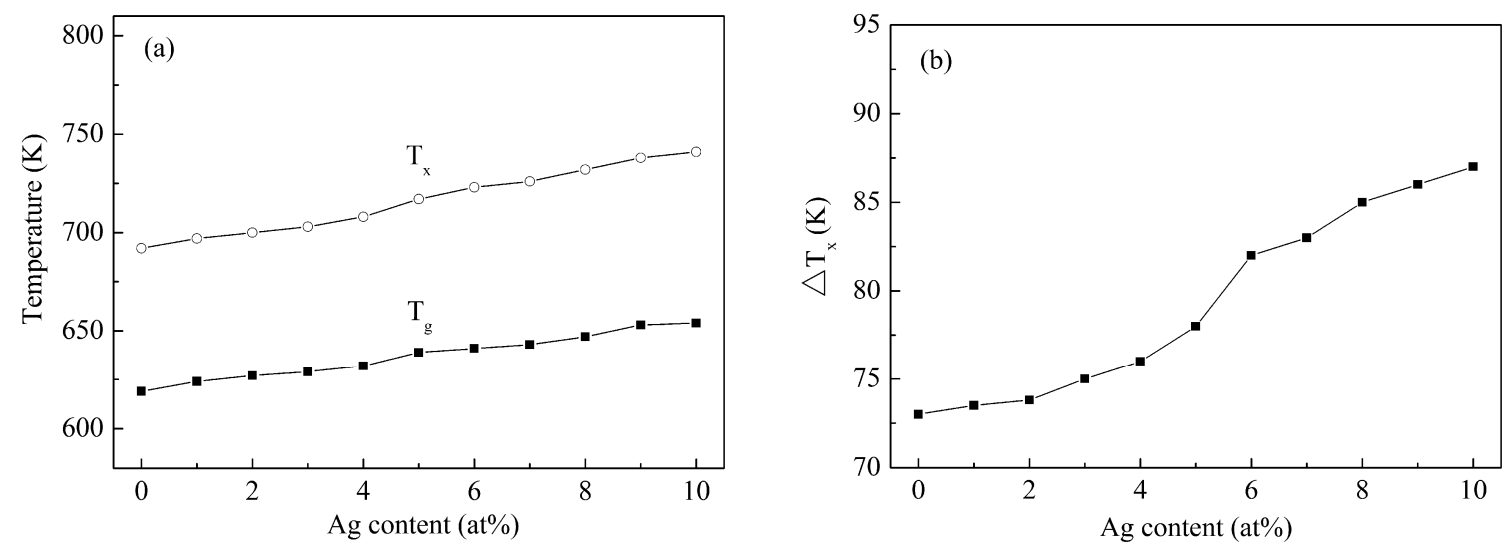

Figure 6. Cont. 


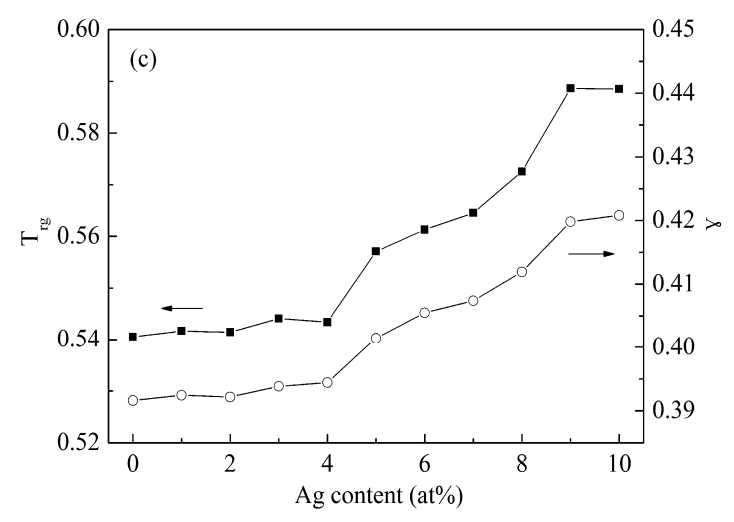

Figure 6. Variations of parameters $T_{\mathrm{g}}, T_{x}(\mathbf{a}) ; \Delta T_{x}(\mathbf{b}) ; T_{\mathrm{rg}}$, and $\gamma(\mathbf{c})$ with the Ag content.

The corrosion behaviors of $\mathrm{Zr}_{70-x} \mathrm{Cu}_{12.5} \mathrm{Ni}_{10} \mathrm{Al}_{7.5} \mathrm{Ag}_{x}$ alloys were characterized by electrochemical polarization in $3.5 \% \mathrm{NaCl}$ aqueous solution open to air at $298 \mathrm{~K}$. The polarization curves of the alloys with different Ag contents are shown in Figure 7. The electrochemical polarization parameters are listed in Table 2. It can be seen that the addition of Ag does not notably change the shape of the polarization curve, and the electrode reaction process of each sample is almost the same. Ag-free alloy was spontaneously passivated with a low current density $\left(I_{\mathrm{corr}}\right)$ of $1.7 \times 10^{-7} \mathrm{~A} \cdot \mathrm{cm}^{-2}$ prior to pitting corrosion $\left(E_{\text {pit }}\right)$ occurring at $144 \mathrm{mV}$, showing a relatively positive corrosion potential $E_{\text {corr }}(-454 \mathrm{mV})$ and a wide passive region $E_{\text {pit }}-E_{\text {corr }}(598 \mathrm{mV})$. However, the $E_{\text {corr }}$ and $E_{\text {pit }}$ become negative-shifting, while the $I_{\text {corr }}$ slightly decreases as more Ag is added. When the Ag concentration reaches $10 \%$, the $E_{\text {corr }}$ and $E_{\text {pit }}$ decrease up to -599 and $-331 \mathrm{mV}$, respectively, leading to $E_{\text {pit }}-E_{\text {corr }}$ decreasing up to $267 \mathrm{mV}$, while $I_{\text {corr }}$ increases up to $1.0 \times 10^{-6} \mathrm{~A} \cdot \mathrm{cm}^{-2}$. In general, the smaller $E_{\text {corr }}$ and the larger $I_{\text {corr }}$ correspond to a worse corrosion resistance. Therefore, the addition of Ag worsens the corrosion resistance of BMG.

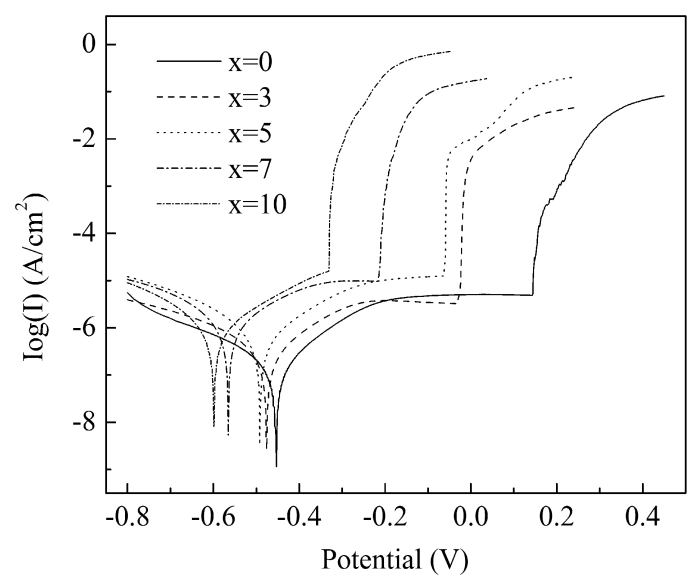

Figure 7. Potentiodynamic polarization of the $\mathrm{Zr}_{70-x} \mathrm{Cu}_{12.5} \mathrm{Ni}_{10} \mathrm{Al}_{7.5} \mathrm{Ag}_{x}$ alloys in $3.5 \% \mathrm{NaCl}$ solution open to air at $298 \mathrm{~K}$.

Table 2. The polarization parameters for the $\mathrm{Zr}_{70-x} \mathrm{Cu}_{12.5} \mathrm{Ni}_{10} \mathrm{Al}_{7.5} \mathrm{Ag}_{x}$ alloys.

\begin{tabular}{ccccc}
\hline Alloys & $\boldsymbol{E}_{\text {corr }}(\mathbf{m V})$ & $\boldsymbol{E}_{\text {pit }}(\mathbf{m V})$ & $\boldsymbol{E}_{\text {pit }}-E_{\text {corr }}(\mathbf{m V})$ & $\boldsymbol{I}_{\text {corr }}\left(\mathbf{A} \cdot \mathbf{c m}^{-2}\right)$ \\
\hline$x=0$ & $-454 \pm 5$ & $144 \pm 4$ & $598 \pm 5$ & $1.7 \pm 0.4 \times 10^{-7}$ \\
$x=3$ & $-476 \pm 4$ & $-26 \pm 2$ & $450 \pm 3$ & $4.1 \pm 0.2 \times 10^{-7}$ \\
$x=5$ & $-492 \pm 3$ & $-62 \pm 2$ & $430 \pm 4$ & $7.6 \pm 0.3 \times 10^{-7}$ \\
$x=7$ & $-565 \pm 6$ & $-213 \pm 3$ & $352 \pm 5$ & $8.2 \pm 0.3 \times 10^{-7}$ \\
$x=10$ & $-599 \pm 5$ & $-331 \pm 4$ & $267 \pm 7$ & $1.0 \pm 0.2 \times 10^{-6}$ \\
\hline
\end{tabular}


In order to better understand the corrosion behaviors of $\mathrm{Zr}_{70-x} \mathrm{Cu}_{12.5} \mathrm{Ni}_{10} \mathrm{Al}_{7.5} \mathrm{Ag}_{x}$ alloys, the morphologies and elemental distribution of the corroded samples were investigated using SEM combined with electron dispersive spectroscopy (EDS). The typical SEM images are presented in Figure 8. A few small pits with sizes around 5-10 $\mu \mathrm{m}$ were observed on the surface of Ag-free alloy. However, as for the 5 at \% Ag alloy, a large number of pits with diameters of 10-20 $\mu \mathrm{m}$ appear on the surface, meaning that the pits formed are a little bigger in size and larger in number than those of the Ag-free alloy. These results suggest that the Ag-bearing alloy exhibits less resistance to pitting corrosion than the Ag-free alloy. The EDS results of chemical composition of the pits, corrosion products, and passive film, marked as A, B, and C in the SEM images, respectively, are listed in Table 3. It is clear that the $\mathrm{Cu}$ contents in the pits and the $\mathrm{O}$ and $\mathrm{Cl}$ contents in the corrosion products are higher than that of the passive film in both alloys. Moreover, $\mathrm{Zr}$ is enriched while $\mathrm{Cu}$ is depleted in the passive film as compared with that of the pits in both alloys. It can be deduced that pitting corrosion occurs through the selective dissolution of $\mathrm{Cu}$ and the formation of oxides and chlorides.
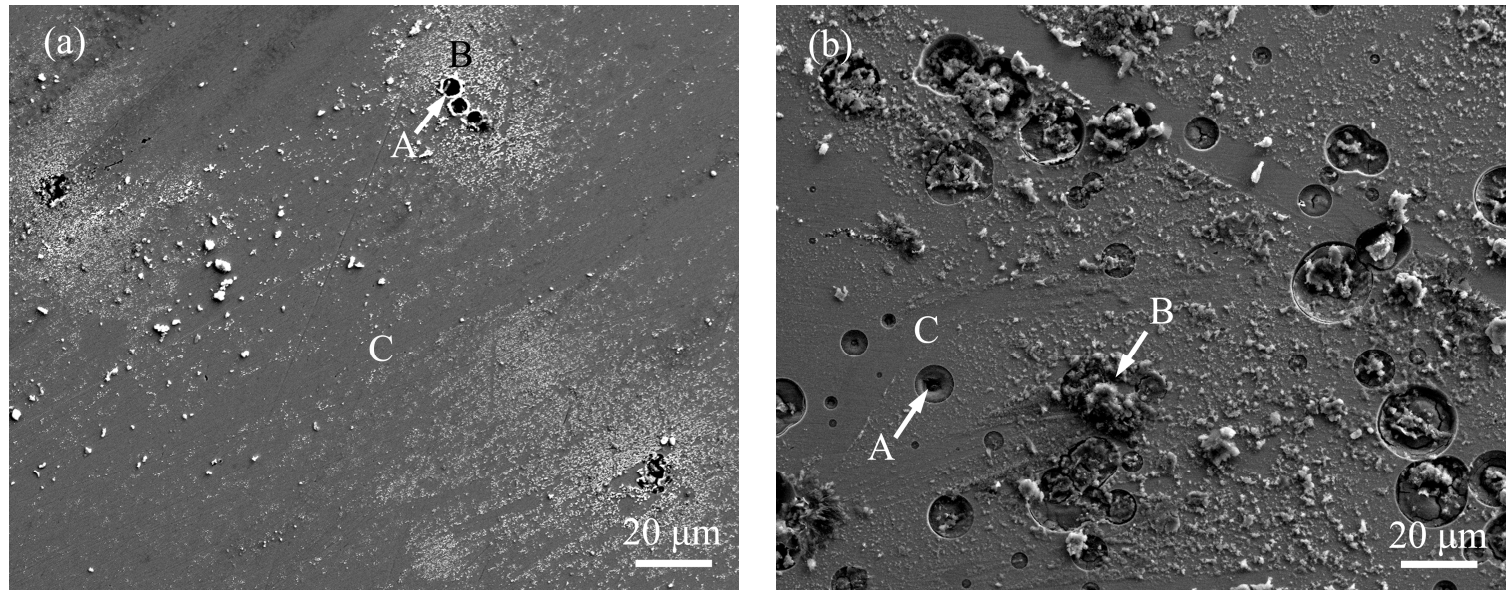

Figure 8. SEM images of the corroded surfaces for the $\mathrm{Zr}_{70} \mathrm{Cu}_{12.5} \mathrm{Ni}_{10} \mathrm{Al}_{7.5}$ (a); and $\mathrm{Zr}_{65} \mathrm{Cu}_{12.5} \mathrm{Ni}_{10} \mathrm{Al}_{7.5} \mathrm{Ag}_{5}$ (b) alloys after polarization.

Table 3. Compositions in the pit (A), corrosion product (B) and passive film (C) by EDS for the $\mathrm{Zr}_{70-x} \mathrm{Cu}_{12.5} \mathrm{Ni}_{10} \mathrm{Al}_{7.5} \mathrm{Ag}_{x}$ alloys after polarization.

\begin{tabular}{ccccccccc}
\hline Alloys & Region & Zr & Cu & Ni & Al & Ag & O & Cl \\
\hline \multirow{3}{*}{$x=0$} & A & 54.23 & 13.45 & 6.72 & 2.31 & - & 22.27 & 1.02 \\
& B & 52.81 & 7.56 & 5.98 & 2.07 & - & 28.15 & 3.43 \\
& C & 61.12 & 7.94 & 6.19 & 2.78 & - & 20.71 & 1.26 \\
\hline \multirow{3}{*}{$x=5$} & A & 48.83 & 14.62 & 6.40 & 1.96 & 3.14 & 23.70 & 1.35 \\
& B & 47.33 & 8.24 & 6.87 & 2.18 & 2.69 & 29.42 & 3.27 \\
& C & 55.27 & 9.21 & 7.15 & 2.66 & 2.97 & 21.73 & 1.01 \\
\hline
\end{tabular}

As mentioned above, the BMG displays localized corrosion instead of generalized corrosion after polarization, confirmed by pitting formation. Because of the difference in the atomic radius and the heat of mixing among the components, an inhomogeneous structure rather than a uniform structure is formed [30], such as chemical and topological short-/medium-range orders, composition segregation or phase separation. Once the BMG is immersed in the electrolyte, the galvanic couples can form among these defects and/or between these defects and the glass matrix, and result in the pitting corrosion. As we know, $\mathrm{Cu}$ is not corrosion resistant in chloride ions containing solution [31]. With the increase of the potential, the passive film becomes unstable, and pitting corrosion takes place accompanied by $\mathrm{Cu}$-selective dissolution and redeposition in the pits. The component $\mathrm{Zr}$ can promote the passivation of the BMG, forming Zr-oxide, which is of a dense and stable structure, and has a highly 
protective ability against corrosion [32,33]. However, the partial substitution of Zr with Ag decreases the content of the $\mathrm{Zr}$ in the alloy, which is involved in passivation, resulting in accelerating the process of chloride penetration, and therefore reduces the corrosion resistance of the BMG.

\section{Conclusions}

$\mathrm{Zr}_{70-x} \mathrm{Cu}_{12.5} \mathrm{Ni}_{10} \mathrm{Al}_{7.5} \mathrm{Ag}_{x}(x=0-10)$ BMGs were successfully fabricated by the copper mold suction-casting method. The glass-forming ability (GFA) and corrosion resistance of the BMGs were investigated. It is revealed that the GFA of $\mathrm{Zr}_{70-x} \mathrm{Cu}_{12.5} \mathrm{Ni}_{10} \mathrm{Al}_{7.5} \mathrm{Ag}_{x}(x=0-10)$ alloys strongly depends on the Ag content. As the Ag content increases, the maximum thickness of the glass phase region initially increases and reaches its maximum around $4.3 \mathrm{~mm}$, at the composition of $\mathrm{Zr}_{65} \mathrm{Cu}_{12.5} \mathrm{Ni}_{10} \mathrm{Al}_{7.5} \mathrm{Ag}_{5}$, and then decreases. The improvement of the GFA is attributed to the enhancement of both the interactions among the constituent elements and the atomic packing density. However, the corrosion resistance of the BMG tends to decrease with the increase of the Ag content, which is originated from the decrease of the $\mathrm{Zr}$ content in the surface film.

Acknowledgments: The authors are grateful for the financial support of the National Natural Science Foundation of China (Grant No. 51401139), the Basic Research Program of Jiangsu Province (Nos. BK20130304 and BK20141193), and the China Postdoctoral Science Foundation (No. 2013M541719).

Author Contributions: Wei Zhou conceived and designed the experiments, and wrote the paper. Caiwei Zhang contributed to the OM and XRD examinations. Jixin Hou contributed to the DSC, DTA and TEM measurements. Minqi Sheng performed the electrochemical polarization measurement. All authors discussed the results.

Conflicts of Interest: The authors declare no conflict of interest.

\section{References}

1. Wang, W.H.; Dong, D.; Shek, C.H. Bulk metallic glasses. Mater. Sci. Eng. R 2004, 44, 45-89. [CrossRef]

2. Schroers, J. Processing of bulk metallic glass. Adv. Mater. 2010, 21, 1566-1597. [CrossRef] [PubMed]

3. Kumar, G.; Tang, H.X.; Schroers, J. Nanomoulding with amorphous metals. Nature 2009, 457, 868-872. [CrossRef] [PubMed]

4. Inoue, A.; Takeuchi, A. Recent development and application products of bulk glassy alloys. Acta Mater. 2011, 59, 2243-2267. [CrossRef]

5. Inoue, A.; Shen, B.L.; Koshiba, H.; Kato, H.; Yavari, A.R. Ultra-high strength above $5000 \mathrm{MPa}$ and soft magnetic properties of Co-Fe-Ta-B bulk glassy alloys. Acta Mater. 2004, 52, 1631-1637. [CrossRef]

6. Schuh, C.A.; Hufnagel, T.C.; Ramamurty, U. Mechanical behavior of amorphous alloys. Acta Mater. 2007, 12, 4067-4109. [CrossRef]

7. Mattern, N. Structure formation in liquid and amorphous metallic alloys. J. Non-Cryst. Solids 2007, 353, 1723-1731. [CrossRef]

8. Lou, H.B.; Wang, X.D.; Xu, F.; Ding, S.Q.; Cao, Q.P.; Hono, K.; Jiang, J.Z. 73 mm-diameter bulk metallic glass rod by copper mould casting. Appl. Phys. Lett. 2011, 99, 051910. [CrossRef]

9. Chen, N.; Martin, L.; Luzguine-Luzgin, D.V.; Inoue, A. Role of alloying additions in glass formation and properties of bulk metallic glass. Materials 2010, 3, 5320-5339. [CrossRef]

10. Inoue, A.; Nishiyama, N.; Kimura, H. Preparation and thermal stability of bulk amorphous $\mathrm{Pd}_{40} \mathrm{Cu}_{30} \mathrm{Ni}_{10} \mathrm{Pd}_{20}$ alloy cylinder of $72 \mathrm{~mm}$ in diameter. Mater. Trans. JIM 1997, 38, 179-183. [CrossRef]

11. Xu, K.; Ling, H.B.; Li, Q.; Li, J.F.; Yao, K.F.; Guo, S.F. Effects of Co substitution for Fe on the glass forming ability and properties of $\mathrm{Fe}_{80} \mathrm{P}_{13} \mathrm{C}_{7}$ bulk metallic glasses. Intermetallics 2014, 51, 53-58. [CrossRef]

12. Wang, J.F.; Wang, L.G.; Guan, S.K.; Zhu, S.Z.; Li, R.; Zhang, T. Effects of boron content on the glass-forming ability and mechanical properties of Co-B-Ta glassy alloys. J. Alloy. Compd. 2014, 617, 7-11. [CrossRef]

13. Zhu, C.L.; Wang, Q.; Wang, Y.M.; Qiang, J.B.; Dong, C. Ni-based B-Fe-Ni-Si-Ta bulk metallic glasses designed using cluster line, minor alloying, and element substitution. Intermetallics 2010, 18, 791-795. [CrossRef]

14. Zheng, Q.; Ma, H.; Ma, E.; Xu, J. Mg-Cu-(Y, Nd) pseudo-ternary bulk metallic glasses: The effects of $\mathrm{Nd}$ on glass-forming ability and plasticity. Scr. Mater. 2006, 55, 541-544. [CrossRef]

15. Zhou, W.; Kong, L.T.; Li, J.F.; Zhou, Y.H. Effects of $\mathrm{Cr}$ addition on glass-forming ability and mechanical properties of Cu-Zr-Al bulk metallic glass. J. Mater. Sci. 2012, 47, 4996-5001. [CrossRef] 
16. Sun, Y.J.; Qu, D.D.; Huang, Y.J.; Liss, K.D.; Wei, X.S.; Xing, D.W.; Shen, J. Zr-Cu-Ni-Al bulk metallic glasses with superhigh glass-forming ability. Acta Mater. 2009, 57, 1290-1299. [CrossRef]

17. Wang, W.H. Roles of minor additions in formation and properties of bulk metallic glasses. Prog. Mater. Sci. 2007, 52, 540-596. [CrossRef]

18. Shen, Y.T.; Xing, L.Q.; Kelton, K.F. Formation and crystallization of ZrCuTi metallic glasses. Philos. Mag. 2005, 85, 3673-3682. [CrossRef]

19. Jiang, Q.K.; Wang, X.D.; Nie, X.P.; Zhang, G.Q.; Ma, H.; Fecht, H.J.; Bendnarcik, J.; Franz, H.; Liu, Y.G.; Cao, Q.P.; et al. Zr-(Cu, Ag)-Al bulk metallic glasses. Acta Mater. 2008, 56, 1785-1796. [CrossRef]

20. Liu, Y.H.; Wang, G.; Wang, R.J.; Zhao, D.Q.; Pan, M.X.; Wang, W.H. Super plastic bulk metallic glasses at room temperature. Science 2007, 315, 1385-1388. [CrossRef] [PubMed]

21. Mattern, N.; Kuhn, U.; Hermann, H.; Ehrenberg, H.; Neuefeind, J. Short-range order of $\mathrm{Zr}_{62-x} \mathrm{Ti}_{x} \mathrm{Al}_{10} \mathrm{Cu}_{20} \mathrm{Ni}_{8}$ bulk metallic glasses. Acta Mater. 2002, 50, 305-314. [CrossRef]

22. Xu, D.H.; Duan, G.; Johnson, W.L. Unusual glass-forming ability of bulk amorphous alloys based on ordinary metal copper. Phys. Rev. Lett. 2004, 92, 245504. [CrossRef] [PubMed]

23. Greer, A.L. Confusion by design. Nature 1993, 366, 303-304. [CrossRef]

24. Takeuchi, A.; Inoue, A. Classification of bulk metallic glasses by atomic size difference, heat of mixing and period of constituent elements and its application to characterization of the main alloying element. Mater. Trans. 2005, 46, 2817-2829. [CrossRef]

25. Miedema, A.R. On the heat of formation of solid alloys II. J. Less Common Met. 1976, 46, 67-83. [CrossRef]

26. Xu, D.H.; Lohwongwatana, B.; Johnson, W.L.; Garland, C. Bulk metallic glass formation in binary Cu-rich alloy series- $\mathrm{Cu}_{100-x} \mathrm{Zr}_{x}\left(x=34,36,38.2,40\right.$ at \%) and mechanical properties of bulk $\mathrm{Cu}_{64} \mathrm{Zr}_{36}$ glass. Acta Mater. 2004, 52, 2621-2624. [CrossRef]

27. Tan, H.; Zhang, Y.; Ma, D.; Feng, Y.P.; Li, Y. Optimum glass formation at off-eutectic composition and its relation to skewed eutectic coupled zone in the La based La-Al-(Cu, Ni) pseudo ternary system. Acta Mater. 2003, 51, 4551-4561.

28. Wang, D.; Li, Y.; Sun, B.B.; Sui, M.L.; Lu, K.; Ma, E. Bulk metallic glass formation in the binary Cu-Zr system. Appl. Phys. Lett. 2004, 84, 4029-4031. [CrossRef]

29. Zhou, W.; Hou, J.X.; Zhong, Z.Z.; Li, J.F. Effect of Ag content on thermal stability and crystallization behavior of Zr-Cu-Ni-Al-Ag bulk metallic glass. J. Non-Cryst. Solids 2015, 411, 132-136. [CrossRef]

30. Gostin, P.F.; Gebert, A.; Schultz, L. Comparison of the corrosion of bulk amorphous steel with conventional steel. Corros. Sci. 2010, 52, 273-281. [CrossRef]

31. Tam, M.K.; Pang, S.J.; Shek, C.H. Corrosion behavior and glass-forming ability of Cu-Zr-Al-Nb alloys. J. Non-Cryst. Solids 2007, 353, 3596-3599. [CrossRef]

32. Cai, A.H.; Xiong, X.; Liu, Y.; An, W.K.; Zhou, G.J.; Luo, Y.; Li, T.L. Corrosion behavior of $\mathrm{Cu}_{55} \mathrm{Zr}_{35} \mathrm{Ti}_{10}$ metallic glass in the chloride media. Mater. Chem. Phys. 2012, 134, 938-944. [CrossRef]

33. Hua, N.B.; Huang, L.; Wang, J.F.; Cao, Y.; He, W.; Pang, S.J.; Zhang, T. Corrosion behavior and in vitro biocompatibility of Zr-Al-Co-Ag bulk metallic glasses: An experimental case study. J. Non-Cryst. Solids 2012, 358, 1599-1604. [CrossRef]

(C) 2016 by the authors; licensee MDPI, Basel, Switzerland. This article is an open access article distributed under the terms and conditions of the Creative Commons Attribution (CC-BY) license (http://creativecommons.org/licenses/by/4.0/). 